BISMA

(Bisnis dan Manajemen)
Volume 12, Issue 2, April 2020, 125-139

ISSN 2549-7790 (Online)

ISSN 1979-7192 (Print)

DOI: 10.26740/bisma.v12n2.p125-139

https://journal.unesa.ac.id/index.php/bisma/index

\title{
Co-shopper and price moderation in the influence of tourist ethnocentrism and brand images on purchase intention
}

\author{
Ika Barokah Suryaningsih* \\ Department of Management, Faculty of Economics and Business, University of \\ Jember \\ Jalan Kalimantan 37, Jember 6812, Indonesia \\ barokahfeb@unej.ac.id
}

\begin{abstract}
Purchase intention provides a motivational effect that always recorded in the consumer mind and influential to their consumption behavior. The purpose of this study was to examine the role of co-shopper and price as moderating variables in the relationship between tourist ethnocentrism and brand image on purchase intention. The population in this study were local tourists who visited Banyuwangi and Osing t-shirt stores. The sampling technique was an accidental sampling that collected data from 100 respondents. The analytical method was Moderated Regression Analysis (MRA). The results showed that tourist ethnocentrism and brand image have a positive effect on purchase intention. The influence of tourist ethnocentrism and brand image on purchase intention is stronger when it moderated by the co-shopper variable. Conversely, the influence of tourist ethnocentrism and brand image on purchase intention was statistically not significantly moderated by price.
\end{abstract}

Keywords: brand image; co-shopper; ethnocentrism; price; purchase intention.

Received: January 22, 2020; Accepted: February 26, 2020; Published: April 7, 2020

*Corresponding author

Email: barokah.feb@unej.ac.id

\section{To cite this document:}

Suryaningsih, I.B. (2020). Co-shopper and price moderation in the influence of tourist ethnocentrism and brand images on purchase intention. BISMA (Bisnis dan Manajemen), 12(April), 125-139. https://doi.org/10.26740/bisma.v12n2.p125-139 


\begin{abstract}
Abstrak
Minat pembelian memberikan efek motivasi yang selalu terekam dalam benak konsumen dan menjadikan suatu keinginan yang sangat berpengaruh terhadap perilakunya. Tujuan penelitian ini adalah untuk menguji peran moderasi co-shopper dan harga pada pengaruh etnosentrisme wisatawan dan citra merek terhadap minat pembelian. Populasi pada penelitian ini adalah wisatawan lokal yang mengunjungi Banyuwangi dan di outlet penjualan kaos Osing. Teknik pengambilan sampel yang digunakan adalah accidental sampling, dengan jumlah responden sebanyak 100 orang. Metode analisis yang digunakan dalam penelitian ini adalah Moderated Regression Analysis (MRA). Hasil penelitian menunjukkan bahwa etnosentrisme dan citra merek berpengaruh positif terhadap minat pembelian. Pengaruh etnosentrisme dan citra merek terhadap minat pembelian souvenir di destinasi wisata lebih kuat jika dimoderasi variabel co-shopper. Sebaliknya, pengaruh etnosentrisme dan citra merek terhadap minat pembelian secara signifikan tidak dimoderasi oleh variabel harga.
\end{abstract}

Kata kunci: citra merek; co-shopper; etnosentrisme; harga; minat pembelian.

\title{
INTRODUCTION
}

Purchase intention provides a motivational effect that always recorded in the consumer mind and influential to their consumption behavior (Kumar \& Sadarangani, 2018). Consumers will fulfill their needs by applying whatever that recorded in their minds to create a purchase intention (Fu et al., 2018). Consumer impulsive purchase occurs mostly in buying souvenirs at tourist destination areas (Sari, 2018). Purchase intentions can be divided into two, namely: exploratory interest which local tourists are continually looking for information that can build and ensure that souvenirs at specific tourist destinations are the products they want; and preferential interest which local tourists keen to buy souvenirs that characterize the area. As a result, the souvenir product usually becomes the first product purchased by the consumer when they visit specific tourist destinations (Boley et al., 2013; Sari, 2018).

Tourism and shopping are inseparable activities (Lee J. \& Lee, 2018; Lee Y. et al., 2009). Tourists spend a third of their total tourism expenditure on shopping, especially to buy souvenirs that characterize tourism areas (Boley et al., 2013). Banyuwangi Regency is currently one of the new alternative tourist destinations. This is marked by a surge in tourists visiting from 4,900,000 in 2017 to 54,000,000 tourists in 2018 (Fanani, 2020).

As a tourist destination, the availability of souvenir products is proliferating. This condition is expected to attract the interest of tourists to buy typical souvenirs of Banyuwangi. There are many unique souvenirs of Banyuwangi, such as T-shirts, keychain, mugs, sandals, udeng (Osing tribe's head coverings) and typical batik of Banyuwangi. Besides, there are a variety of snacks that can be used as souvenirs, namely bagiak, klemben, various nuts, spicy macaroni, banana sale, various sweets, various chips and crackers, bidaran (a typical cake of Banyuwangi), and 
Banyuwangi coffee (Rachmaningtyas, 2016). Among these all products, Osing tshirt is mostly favored by the tourist.

The native citizen of Banyuwangi Regency is the Osing tribe in which Osing culture attracts local and international tourists to visit Banyuwangi. Based on information from several souvenir shops in Banyuwangi, t-shirt products with Osing language design have always been the choice of local tourists (Hariyanto, 2019). Osing t-shirt introduces Osing culture and language, such as: "osing deles," "byek," "ruwed teter," "turn", "ono paran", "isun osing", in its t-shirt design. The high sales of Osing t-shirts compared to other souvenir products reflects Banyuwangi, specifically Osing people pride on their local cultures are widely known as ethnocentrism (Riefler \& Diamantopoulos, 2009). The regionalism pride and the image of the tourist destination (brand image) poured through souvenir products have added attractiveness and uniqueness which attract tourists to buy the products. Thus, the purpose of this study is to examine the role of co-shopper and price as the moderating variable on the influence of tourist ethnocentrism and brand image on purchase intention to local souvenirs of Banyuwangi.

\section{Ethnocentrism}

The concept of ethnocentrism generally shows the pride of a group of people to view themselves as the center of trust and interpreting other groups based on the viewpoints adopted in their groups (Riefler \& Diamantopoulos, 2009; Watson, 2000). Therefore, this study uses the CETSCALE (Consumer Ethnocentrism Tendencies Scale) by Shimp and Sharma (1987), to measure a tendency of consumer ethnocentrism to interest in purchasing local products. Meanwhile, based on their study, the interest in purchasing souvenirs is not only influenced by tourist interest in local culture but also influenced by the image of the product itself (brand image).

\section{Brand Image}

Brand image is a series of consumer beliefs about a particular brand determined by the inherency of brand association with the consumer mind (Kotler \& Keller, 2016). Building the right brand image in the consumer mind is mandatory for the company because it can reduce the search costs of a consumer of particular brands and also becomes a symbol that distinguishes one product from another product (Semuel \& Lianto, 2014). Brand image is proven to have a significant effect on purchase intention (Tong \& Li, 2013), a product with a good brand image causes consumers to tend to re-purchase it (Jalilvand \& Samiei, 2012; Lee J. \& Lee, 2018).

\section{Co-Shopper}

Tourists tend to look for new things when buying souvenirs (Lee Y. et al., 2009). However, consumer shopping behavior is frequently influenced by friends or relative who accompany consumers to shopping or known as co-shopper ( $\underline{\text { Yim }}$ et al., 2014; Yim Wong et al., 2008). Consumer shopping behavior and motivation 
can vary with the presence of several types of co-shopper motivation (Merrilees \& Miller, 2019; Tongue et al., 2010). Co-shopper's social motivation includes 'to have fun, comfort, socialize, or tend to make friends' (Tongue et al., 2010; Yim et al., 2014). Furthermore, there is assistance motivation includes 'giving moral support to make purchase decisions, applying expertise in selecting products, and accompanying family as a shopping partner' (Tongue et al., 2010; Yim et al., 2014).

There are some previous research about the co-shopper influence on shopping motivation that consistent with the results of previous studies which concluded that co-shopper provides information that can help shoppers to reduce risk and uncertainty and to increase confidence in decision-making (Insch et al., 2011). When shopping with co-shoppers, the consumer usually becomes more impulsive so that they will spend more time shopping, consider to spend more money and finalize more purchase (Kim \& Thorndike, 2000; Tongue et al., 2010; Yim et al., 2014).

\section{Price}

Consumer purchase intention is often influenced by product price. Price is the amount of money charged for a product or service (Kotler \& Keller, 2016) or the amount of value exchanged by consumers for the benefits of owning or using the product or service (Bizumic, 2019; Seidenfuss et al., 2013). In determining the pricing strategy, there are several things to consider price affordability and price conformity with the product or service quality; price competitiveness with similar products from competitors, and price match with benefits offered by the products (Jean-Pierre \& Porral, 2016; Swani \& Yoo, 2010).

\section{Purchase Intention}

Purchase intention has a motivational effect that is always recorded in the minds of consumers and makes a desire that is very influential (Boley et al., 2013), they will apply whatever is recorded in the consumer's mind (Fu et al., 2018; Jalilvand \& Samiei, 2012; Kim \& Thorndike Pysarchik, 2000). There are two indicators of buying interest in this study (Ferdinand, 2002), namely: first, explorative interest, that is, local tourists are continually looking for information that can build and ensure that $O$ sing shirts are the product they want to generate interest in buying t-shirts the $O$ sing. Second, preferential interest, i.e. local tourists will increase their desire to buy Osing shirts so that they can show that Osing shirts are the first product they always buy when visiting Banyuwangi. The conceptual framework of the study is presented in figure 1. 
Ika Barokah Suryaningsih Co-shopper and price moderation in the influence of tourist ethnocentrism and brand images on purchase intention

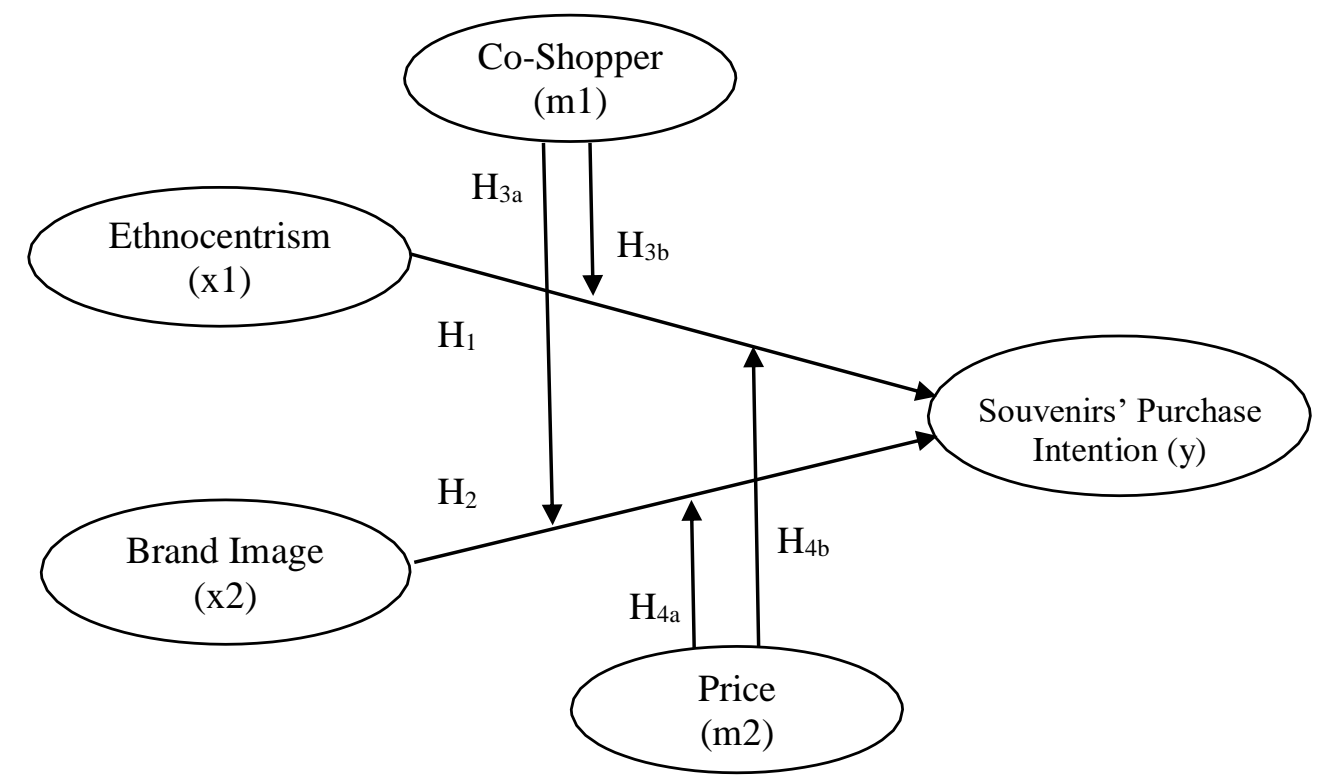

Figure 1. Conceptual Framework

\section{Hypothesis}

H1: Ethnocentrism affects souvenirs' purchase intention.

$\mathrm{H} 2$ : Brand image affects souvenirs' purchase intention.

H3a: Co-shopper moderates the effect of ethnocentrism on souvenirs' purchase intention.

$\mathrm{H} 3 \mathrm{~b}$ : Co-shopper moderates the effect of brand image on souvenirs' purchase intention.

H4a: Price moderates the effect of ethnocentrism on souvenirs' purchase intention.

$\mathrm{H} 4 \mathrm{~b}$ : Price moderates the effect of brand image on souvenirs' purchase intention.

\section{METHODS}

This research uses analytical research; that is, the research explains a central problem, and there is a hypothesis test and analyzes the data obtained (Sugiyono, 2016). The population in this study are local tourists who visit Banyuwangi. The sampling technique is an accidental sampling that selects 100 local tourists of Banyuwangi who visit $O$ sing t-shirts stores. The type of data is quantitative data that collected by questionnaire by 1-5 point Likert scale design.

Shimp and Sharma (1987) developed the consumer ethnocentrism tendency scale (CETSCALE). CETSCALE measures the tendency of consumer ethnocentrism attitude towards the product to be purchased (Luque-martõ et al., 2000; Shimp \& Sharma, 1987). Shimp \& Sharma (1987) determines that 17 indicators can be used to measure ethnocentrism. However, in this study only used four indicators as the indicators can be adjusted to the needs and conditions of existing research objects (Sharma, 2015).

The research instrument test before conducting the Moderated Regression Analysis (MRA) is validity, reliability, and normality tests. The validity test uses 
Pearson product-moment correlation analysis, by looking for the relationship of each statement with a total score. Then the results are compared with a significance level of 5\%. Reliability testing is determined by Cronbach Alpha statistics. The reliable variables are determined by Cronbach Alpha value of more than 0.60 (Ghozali, 2016). Meanwhile, the normality test uses the Kolmogorov-Smirnov-test using a confidence value $(\alpha)$ of 0.05 . If the significance level is more than 0.05 , then the data is usually distributed, and if the significance level is less than 0.05 , then the data is not normally distributed.

The analytical method used in this study is Moderated Regression Analysis (MRA). Moderated Regression Analysis (MRA) or interaction test is a special application of multiple linear regression (Ghozali, 2016) where the regression equation contains interactive elements (multiplication of two or more independent variables) with the equation formula (1).

$y=a+b_{1} x_{1}+b_{2} x_{2}+b_{3} x_{1} x_{2}+e$

The multiplication variable between $\mathrm{x} 1$ and $\mathrm{x} 2$ is also called a moderate variable because it illustrates the moderating effect of the $\mathrm{x} 2$ variable on the relationships $\mathrm{x} 1$ and $\mathrm{y}$. Whereas the variables $\mathrm{x} 1$ and $\mathrm{x} 2$ are the direct influence of the variables $\mathrm{x} 1$ and $\mathrm{x} 2$ on $\mathrm{y}$. Because this study examines two independent variables, two moderation variables, and one dependent variable, then the equation formula (2).

$y=a+b_{1} x_{1}+b_{2} x_{2}+b_{3} x_{1} m_{1}+b_{4} x_{2} m_{1}+b_{5} x_{1} m_{2}+b_{6} x_{2} m_{2}+e$

Note:

$\mathrm{y}=$ souvenirs' purchase intention

$\mathrm{x}_{1} \quad=$ ethnocentrism

$\mathrm{x}_{2}=$ brand image

$\mathrm{m}_{1} \quad=$ co-shopper

$\mathrm{m}_{2} \quad=$ price

$\mathrm{x}_{1} \mathrm{~m}_{1}=$ interaction of ethnocentrism and co-shopper

$\mathrm{x}_{2} \mathrm{~m}_{1}=$ interaction of brand image and co-shopper

$\mathrm{x}_{1} \mathrm{~m}_{2}=$ interaction of ethnocentrism and price

$\mathrm{x}_{2} \mathrm{~m}_{2}=$ interaction of brand image and price

$\mathrm{a}=$ consant

$\mathrm{b}_{1-6}=$ regression coefficient

e $=$ disturbance error 
Ika Barokah Suryaningsih

Co-shopper and price moderation in the influence of tourist ethnocentrism and brand images on purchase intention

\section{RESULT AND DISCUSSION Validity test}

A validity test is used to test whether the results of the questionnaire that has been distributed are valid or not (Ghozali, 2016). The validity test uses Pearson's product-moment correlation analysis that identifies the relationship of each statement to the total score. Then the results are compared with a critical level of the significance level of $5 \%$. If the calculated value is higher than the table, then the statement item is declared valid. Conversely, if the r-count is smaller than the r-table, the statement item is declared invalid. The results of the validity test in this study can be seen in Table 1. Based on Table 1, the results of the validity test of each indicator of all variables have $r$ counts higher than $r$ tables so that it can be interpreted that all variables are valid to be examined in this research.

\begin{tabular}{|c|c|c|c|c|c|}
\hline Variable & Indicator & $\mathbf{r}$ table & $\mathbf{r}$ count & $\begin{array}{c}\text { p- } \\
\text { value }\end{array}$ & Exp \\
\hline \multirow[t]{4}{*}{$\begin{array}{l}\text { Ethnocentrism } \\
\text { (x1) }\end{array}$} & $\begin{array}{l}\text { Buying souvenirs produced by the local } \\
\text { store in the tourism area. }\end{array}$ & 0,159 & 0,862 & 0,000 & Valid \\
\hline & $\begin{array}{l}\text { Buying souvenirs will also increase the } \\
\text { level of the people's economy. }\end{array}$ & 0,159 & 0,831 & 0,000 & Valid \\
\hline & Love the tourist area souvenirs. & 0,159 & 0,832 & 0,000 & Valid \\
\hline & $\begin{array}{l}\text { Buying typical souvenirs in tourist areas } \\
\text { is the best choice }\end{array}$ & 0,159 & 0,855 & 0,000 & Valid \\
\hline \multirow[t]{3}{*}{ Brand Image (x2) } & Brand awareness & 0,159 & 0,852 & 0,000 & Valid \\
\hline & Favorite brand & 0,159 & 0,790 & 0,000 & Valid \\
\hline & Brand uniqueness & 0,159 & 0,871 & 0,000 & Valid \\
\hline \multirow[t]{2}{*}{ Co-Shopper (m1) } & Trust the consideration of friends & 0,159 & 0,676 & 0,000 & Valid \\
\hline & Buy more with friends & 0,159 & 0,609 & 0,000 & Valid \\
\hline \multirow{4}{*}{ Price $(\mathrm{m} 2)$} & Affordability of prices & 0,159 & 0,751 & 0,000 & Valid \\
\hline & Price match with the quality & 0,159 & 0,810 & 0,000 & Valid \\
\hline & Price competitiveness & 0,159 & 0,726 & 0,000 & Valid \\
\hline & Price matches benefits & 0,159 & 0,821 & 0,000 & Valid \\
\hline \multirow{2}{*}{$\begin{array}{l}\text { Purchase Intention } \\
\text { (y) }\end{array}$} & Interest in explorative purchases & 0,159 & 0,890 & 0,000 & Valid \\
\hline & Preferential purchase intention & 0,159 & 0,903 & 0,000 & Valid \\
\hline
\end{tabular}

Source: Data Processed

\section{Reliability Test}

A reliability test measures whether the measurement instrument used is consistent or not for further research (Ghozali, 2016). Alpha reliability test method ( $\alpha$ ) used is Cronbach's alpha method. The variable is said to be reliable if the variable has a Cronbach alpha value of more than 0.60 . The reliability test results in this study can be seen in Table 2 . The reliability test results of all variable: ethnocentrism (X1), brand image (X2), co-shopper (m1), price (m2) and purchase intention (Y) have a Cronbach's alpha value higher than the reliability standard so that it can be interpreted that all statements used as a reliable research data collection instrument. 
Table 2. Reliability Tests

\begin{tabular}{lccc}
\hline \multicolumn{1}{c}{ Variable } & $\begin{array}{c}\text { Cronbach's } \\
\text { Alpha }\end{array}$ & $\begin{array}{c}\text { Critical Value of } \\
\text { Reliability }\end{array}$ & Exp \\
\hline Ethnocentrism (X1) & 0,762 & 0,60 & Reliable \\
Brand Image (X2) & 0,787 & 0,60 & Reliable \\
Co-Shopper (M1) & 0,768 & 0,60 & Reliable \\
Price (M2) & 0,760 & 0,60 & Reliable \\
Purchase Intention (Y) & 0,755 & 0,60 & Reliable \\
\hline
\end{tabular}

Source: Data Processed

\section{Data Normality Test}

Data normality test measures whether the data obtained is normally distributed or not (Ghozali, 2016). The normality test in this study used the Kolmogorov-Smirnov-test by confidence value $(\alpha)$ of 0.05 . If the significance level is more than 0.05 , then the data is normally distributed and if the significance level is less than 0.05 , then the data is not normally distributed. Data normality test results are presented in Table 3 .

Table 3 Data Normality Test

\begin{tabular}{lccl}
\hline \multicolumn{1}{c}{ Variable } & Asymp. Sig. (2-tailed) & A & \multicolumn{1}{c}{ Explanation } \\
\hline Ethnocentrism (X1) & 0,142 & 0,05 & Normal distribution \\
Brand Image (X2) & 0,098 & 0,05 & Normal distribution \\
Co-Shopper (M1) & 0,124 & 0,05 & Normal distribution \\
Price (M2) & 0,133 & 0,05 & Normal distribution \\
Purchase Intention (Y) & 0,200 & 0,05 & Normal distribution \\
\hline
\end{tabular}

Source: Data Processed

\section{Moderated Regression Analysis (MRA)}

Based on data processing with Moderated Regression Analysis (MRA) using SPSS 24, the following results were obtained. Appendix 1 shows the coefficient of determination of this research model. The coefficient of determination of the results of the analysis in the table is 0.641 . It can be stated that the interest of local tourists to buy Banyuwangi typical souvenirs is influenced by ethnocentrism, brand image, co-shopper, and price, as well as moderator variables of $64.1 \%$. While other variables outside the model influence the remaining about $35.9 \%$.

Based on Appendix 2, the results of the F test indicate that ethnocentrism, brand image, co-shopper, and price collectively influence the purchase intention with a probability of significance of 0,000 . However, partially, the influence of each independent variable and moderation variable needs to be observed based on the results of the t-test as in Appendix 3.

Moderated Regression Analysis test results show that ethnocentrism $(\beta \times 1=$ $0.211)$ with a $\mathrm{p}$-value of 0.001 , and brand image $(\beta \times 2=0.342)$ with a $\mathrm{p}$-value of 0.000 reflects a positive effect on purchase intention. The role of co-shopper moderation also affects ethnocentrism on purchase intention $(\beta \times 1 \mathrm{~m} 1=0.765)$ with a p-value of 0.000 . Meanwhile, co-shopper moderation on the brand image has a 
Ika Barokah Suryaningsih Co-shopper and price moderation in the influence of tourist ethnocentrism and brand images on purchase intention

positive effect on the brand image influence on purchase intention $(\beta \times 2 \mathrm{~m} 1=0.857)$ with a $\mathrm{p}$-value of 0,000 . However, the role of price moderation has no significant effect on ethnocentrism on purchase intention $(\beta \times 1 \mathrm{~m} 2=0.583)$ with a $p$-value of 0.088 .

Meanwhile, the price moderation on the brand image harms the brand image influence on purchase intention $(\beta \times 2 \mathrm{~m} 2=-0.554)$ with a $\mathrm{p}$-value of 0.000 . Thus, the mathematical functions of the Moderated Regression Analysis test results can be shown in formula (3). The result of research model based on the conceptual framework is presented in Figure 2.

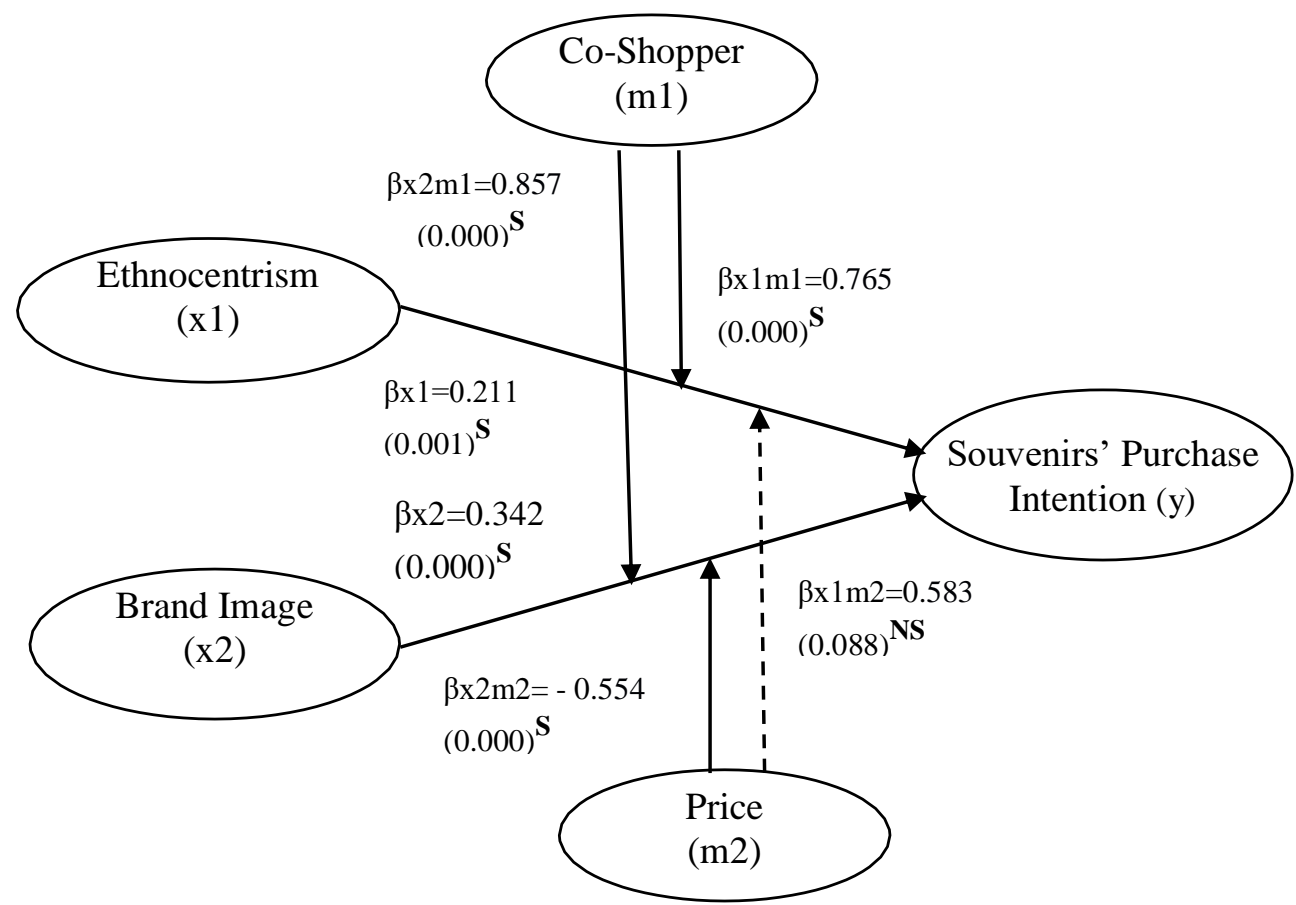

Figure 2. Co-shopper and Prices Moderation Role Models

\section{Discussion}

Tourist ethnocentrism has a positive influence on purchasing interests supports the statement of Pentz et al. (2017). It can be stated that the higher the

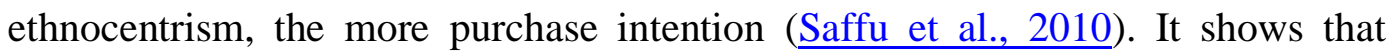
respondents' ethnocentrism influences their behavior to purchase Osing t-shirts. The motivation of respondents to buy Osing t-shirts reflects their attitudes to love and pride in local culture (Kumar \& Sadarangani, 2018) and also the design of Osing t-shirts that competitive with other t-shirts from the non-local brand.

The results of this study are in line with previous research conducted by (Monalisa, 2015), which shows that consumer ethnocentrism has a significant effect on purchase intentions. According to (Rusdan et al., 2018; Sari, 2018; Watson, 
2000), consumers with high levels of ethnocentrism would be more dominant in buying local products and more careful in evaluating a product before they make a purchase. However, this study is not in line with the findings (Tong \& Li, 2013; Tongue et al., 2010) which stated that young consumer usually have low ethnocentrism, even though they know that buying local products reflects their country pride, but they still prefer branded product than the local one (Tong \& Li, $\underline{2013}$.

The high ethnocentrism attitude shows that local tourists are supportive of products with regional characteristics, including culture, and language of the $O$ sing tribe. The majority of respondents in this study were men aged 17-25 years who tended to be more casual in dressing by wearing t-shirts. At this age, they tend to update information about $O$ sing t-shirts from various social media which caused them interested in exploring local culture (Lee Y. et al., 2009) and influenced them to upload their fashion knowledge and style on social media to get appreciation. It reflects that young consumers generally need self-actualization or praised by posting everything related to the tourism destination they have visited (Lee Y. et al., 2009).

Brand image has a positive effect on the purchase intention of Osing t-shirts, so the better the brand image of a product, the higher consumer's purchase intention will be (Chieh et al., 2018; Tong \& Li, 2013). This study revealed that respondents have the perception that $O$ sing t-shirts have authenticity (Kumar \& Sadarangani, 2018) so that it makes the consumers remember the Osing t-shirt brand. Hence, tourists tend to look for detailed information about $O$ sing shirts to build confidence in purchase decision making. It proves that the interest in purchasing $O$ sing t-shirts is caused by product characteristics that do not impose by souvenir shirts from other tourism destination (Jalilvand \& Samiei, 2012).

The results of this study are in line with previous research conducted by (Ersi \& Semuel, 2014), which shows that brand image influences purchase intention. However, the results of this study do not support the findings (Chieh et al., 2018), due to different research objects. The findings (Lee J. \& Lee, 2018) state that fashion product brand image does not affect purchase intention. On the other hand, the purchase intention of fashion products is more influenced by the image of the company or manufacturer (Lee J. \& Lee, 2018).

The role of co-shopper moderation is proven to influence purchase intention. This is evidenced by the co-shopper moderation coefficient that more significant than the ethnocentrism coefficient and brand image on purchase intention. Coshopper moderation coefficient on brand image towards purchase intention (Yim et al., 2014) is higher than the co-shopper moderation coefficient on ethnocentrism on purchase intention (Tongue et al., 2010). As previous research conducted (Yim et al., 2014), it shows that co-shopper has a significant role in purchasing decisions. Co-shopper can cause tourists to spend more time to do shopping. Also, the co- 
shopper will influence the number of goods to be purchased so that tourists will spend more money to buy souvenirs. According to (Merrilees \&Miller, 2019), what is meant by co-shopper, in this case, is a friend when tourists visit specific tourist destinations. In theory, co-shopper is one of a reference group that can influence a person's purchasing decisions (Kotler \& Keller, 2016).

Price has not significantly moderated ethnocentrism and brand image towards the purchase of souvenirs. This research proves that the price harms souvenir purchase intentions. Confidence in the brand image will not create purchase intention if the affordability of prices does not match by tourists' financial ability or the lack of price suitability with the benefits of souvenirs to consumers (Bizumic, 2019; Seidenfuss et al., 2013). In contrast to findings (Jean-Pierre \& Porral, 2016), prices do not influence consumers to make purchases simply because of the store's image. Likewise, the results of the study (Swani \& Yoo, 2010), prices can directly influence purchase intention. However, prices cannot influence purchase intention through brand image mediation.

Moreover, price moderation in ethnocentrism on purchase intention is not proven. Although (Seidenfuss et al., 2013) states that the purchase of specific products such as cars, fashion, and electronics is strongly influenced by prices, especially for lower and middle-income segments. However, in this study, the tourist purchase intention on souvenirs is not influenced by price (Jean-Pierre \& Porral, 2016; Swani \& Yoo, 2010). The high sales of Osing t-shirts are influenced by a sense of love for local cultures and product authenticity (Riefler \& Diamantopoulos, 2009; Boley et al., 2013; Fu et al., 2018).

\section{CONCLUSION}

Based on the results of the study, ethnocentrism and brand image proved to have a positive effect on purchase intention. The consumer interest in purchasing souvenirs at tourist destinations is stronger if moderated by co-shopper. Meanwhile, the price has not significantly moderated ethnocentrism and brand image towards the purchase of souvenirs. This research proves that the price harms souvenir purchase intentions.

The practical implication of this study is that the Osing t-shirt producers are expected to maintain the brand image of the t-shirts. Also, producers must maintain the characteristics and authenticity of $O$ sing t-shirts as souvenirs that preserve local culture. The theoretical implications of this research are to enrich the repertoire of the field of marketing science related to factors that encourage consumers to purchase products in the realm of tourism marketing and its derivative industries. This study also has limitations in variables that influence the purchase intention, so that future researchers can develop this research model by adding more variables such as psychological price, product differentiation, and the use of different analytical tools such as SEM analysis. 
BISMA (Bisnis dan Manajemen)

Volume 12 Issue 2, April 2020

E-ISSN 2549-7790, P-ISSN 1979-7192

Page 125-139

\section{REFERENCES}

Bizumic, B. (2019). Effects of the dimensions of ethnocentrism on consumer ethnocentrism: An examination of multiple mediators. International Marketing Review, 36(5), 748-770. http://doi.org/10.1108/IMR-04-2018$\underline{0147}$.

Boley, B., Magnini, V. P., \& Tuten, T. L. (2013). Social media picture posting and souvenir purchasing behavior: Some initial findings. Tourism Management, 37(August 2013), 27-30. http://doi.org/10.1016/j.tourman.2012.11.020.

Chieh, Y., King, B., \& Lee, H. (2018). Behavioral intentions of arts festival tourists. Journal of Destination Marketing \& Management, 10(December 2018), 6167. http://doi.org/10.1016/j.jdmm.2018.06.004.

Ersi, D. Y., \& Semuel, H. (2014). Analysis CRM, kepuasan pelanggan dan loyalitas produk. Jurnal Manajemen Pemasaran. 8(1), 1-8. http://doi.org/10.9744/pemasaran.8.1.1-8.

Fanani, A. (2020). 2019, kunjugan Wisatawan ke Banyuwangi Tembus 5,4 Juta. Acces from website Detik News: https://news.detik.com/berita-jawa-timur/d4864264/2019-kunjugan-wisatawan-ke-banyuwangi-tembus-54-jutal on 19 January 2020.

Ferdinand, A. (2002). Pengembangan Minat Beli Merek Ekstensi. Universitas Diponegoro.

Fu, Y., Liu, X., Wang, Y., \& Chao, R. F. (2018). How experiential consumption moderates the effects of souvenir authenticity on behavioral intention through perceived value. Tourism Management, 69(December 2018), 356-367. http://doi.org/10.1016/j.tourman.2018.06.023.

Ghozali, I. (2016). Aplikasi Analisis Multivariate denganProgram IBM SPSS 23 (VIII). Badan Penerbit Universitas Diponegoro.

Insch, A., Prentice, R. S., \& Knight, J. G. (2011). Retail buyers' decision-making and buy national campaigns. Australasian Marketing Journal, 19(4), 257266. http://doi.org/10.1016/j.ausmj.2011.07.003.

Jalilvand, M. R., \& Samiei, N. (2012). The effect of electronic word of mouth on brand image and purchase intention: An empirical study in the automobile industry in Iran. Marketing Intelligence and Planning, 30(4), 460-476. http://doi.org/10.1108/02634501211231946.

Jean-Pierre, L.-M., \& Porral, C. C. (2016). Food private label brands: the role of consumer trust on loyalty and purchase intention. British Food Journal, 12(4), 564-578. http://doi.org/10.1108/bfj-08-2015-0299.

Kim, S., \& Thorndike Pysarchik, D. (2000). Predicting purchase intentions for uninational and bi-national products. International Journal of Retail \& 
Ika Barokah Suryaningsih Co-shopper and price moderation in the influence of tourist ethnocentrism and brand images on purchase intention

Distribution Management, 28(6), 280-291. http://doi.org/10.1108/09590550010328544.

Kotler, P., \& Keller, K. L. (2016). Marketing Management 15 Global Edition. New York: John Willey and Sons, inc. http://doi.org/10.1080/08911760903022556.

Kumar, S., \& Sadarangani, P. (2018). An Empirical Study on Shopping Motivation among Generation Y Indian. Global Business Review. http://doi.org/10.1177/0972150918807085.

Lee, J., \& Lee, Y. (2018). Effects of multi-brand company's CSR activities on purchase intention through a mediating role of corporate image and brand image. Journal of Fashion Marketing and Management, 22(3), 387-403. http://doi.org/10.1108/JFMM-08-2017-0087.

Lee, Y., Kim, S., Seock, Y., \& Cho, Y. (2009). Tourists ' attitudes towards textiles and apparel-related cultural products: A cross-cultural marketing study. Tourism Management, 30(5), 724-732. http://doi.org/10.1016/j.tourman.2008.10.007.

Luque-martõ, T., Iba, Â., \& Barrio-garcõ, S. (2000). An assessment of the reliability and validity of the CETSCALE in Spain Consumer ethnocentrism measurement. European Journal of Marketing, 34(11), 1353-1373. http://doi.org/10.1108/03090560010348498.

Merrilees, B., \& Miller, D. (2019). Companion shopping: the influence on mall brand experiences. Marketing Intelligence and Planning, 37(4), 465-478. http://doi.org/10.1108/MIP-08-2018-0340.

Monalisa, T. (2015). Pengaruh Etnosentrisme Konsumen Kota Malang Terhadap Niat Beli Buah Lokal. Parsimonia, 2(2), 23-33. Acces from website Parsimonia:

http://jurnal.machung.ac.id/index.php/parsimonia/article/view/17/.

Pentz, C., Terblanche, N., \& Boshoff, C. (2017). Antecedents and Consequenses of Consumer Ethnocentrism: Evidence from South Africa. International Journal of Emerging Markets, 12(2). http://doi.org/10.1108/IJoEM-09-2015$\underline{0189 .}$.

Riefler, P., \& Diamantopoulos, A. (2009). Consumer cosmopolitanism : Review and replication of the CYMYC scale. Journal of Business Research, 62(4), 407-419. http://doi.org/10.1016/j.jbusres.2008.01.041.

Rusdan, B. I., Sulhaini, \& Dayani, R. (2018). Pengaruh Kecenderungan Konsumen Etnosentrisme Dan Kepercayaan Produk Domestik Terhadap Keinginan Untuk Membeli Produk Elektronik di Kota Mataram NTB. Distribusi, 6(1). http://doi.org/10.29303/distribusi.v6i1.26.

Saffu, K., Walker, J. H., \& Mazurek, M. (2010). The role of consumer 
ethnocentrism in a buy national campaign in a transitioning country: Some evidence from Slovakia. International Journal of Emerging Markets, 5(2), 203-226. http://doi.org/10.1108/17468801011031829.

Sari, V. P. (2018). Pengaruh Consumer Ethnocentrism Dan Citra Perusahaan Terhadap Minat Beli Dengan Citra Merek Global Sebagai Variabel Mediasi [Universitas Negeri Yogyakarta]. Acces from website Eprints@UNY: http://eprints.uny.ac.id/id/eprint/59668.

Seidenfuss, K. U., Kathawala, Y., \& Dinnie, K. (2013). Regional and country ethnocentrism: broadening ASEAN origin perspectives. Asia Pacific Journal of Marketing and Logistics, 25(2), 298-320. http://doi.org/10.1108/13555851311314077.

Semuel, H., \& Lianto, A. S. (2014). Analisis E-WOM, Brand Image ,Brand Trust Dan Minat Beli Produk Smartphone Di Surabaya. Jurnal Manajemen Pemasaran, 8(2). http://doi.org/10.9744/pemasaran.8.2.47-54.

Sharma, P. (2015). Consumer ethnocentrism: Reconceptualization and crosscultural validation. Journal of International Business Studies, 46(3), 381389. http://doi.org/10.1057/jibs.2014.42.

Shimp, T. A., \& Sharma. (1987). Consumer Ethnocentrism: Construction and Validation of the CETSCALE. Journal of Marketing Research, 24(August), 280-289. http://doi.org/10.2307/3151638.

Sugiyono. (2016). Metode Penelitian Kuantitatif, Kualitatif dan $R \& D$ (4th ed.). Alfabeta.

Swani, K., \& Yoo, B. (2010). Interactions between price and price deal. Journal of Product and Brand Management, 19(2), 143-152. http://doi.org/10.1108/10610421011033494.

Tong, X., \& Li, C. (2013). Impact of brand personality and consumer ethnocentrism in China's sportswear market. Asia Pacific Journal of Marketing and Logistics, 25(3), 491-509. http://doi.org/10.1108/APJML-08-2012-0081.

Tongue, M. A., Otieno, R., \& Cassidy, T. D. (2010). Evaluation of sizing provision among high street retailers and consumer buying practices of children's clothing in the UK. Journal of Fashion Marketing and Management, 14(3), 429-450. http://doi.org/10.1108/13612021011061870.

Watson, J. J. (2000). Consumer ethnocentrism and attitudes toward domestic and foreign products. European Journal of Marketing, 34(9), 1149-1166. http://doi.org/10.1108/03090560010342520.

Yim, M. Y. C., Yoo, S. C., Sauer, P. L., \& Seo, J. H. (2014). Hedonic shopping motivation and co-shopper influence on utilitarian grocery shopping in 
Ika Barokah Suryaningsih Co-shopper and price moderation in the influence of tourist ethnocentrism and brand images on purchase intention

superstores. Journal of the Academy of Marketing Science, 42(5), 528-544. http://doi.org/10.1007/s11747-013-0357-2.

Yim Wong, C., Polonsky, M. J., \& Garma, R. (2008). The impact of consumer ethnocentrism and country of origin sub-components for high involvement products on young Chinese consumers' product assessments. Asia Pacific Journal of Marketing and Logistics, 20(4), 455-478. http://doi.org/10.1108/13555850810909759.

Appendix 1. Coefficient of Determination

\begin{tabular}{llcrr}
\hline \multicolumn{1}{c}{ Model } & \multicolumn{2}{c}{ Model Summary } \\
R & R Square & $\begin{array}{c}\text { Adjusted R } \\
\text { Square }\end{array}$ & $\begin{array}{c}\text { Std. Error of the } \\
\text { Estimate }\end{array}$ \\
\hline 1 & $.801^{\mathrm{a}}$ & .641 & .621 & 2.98400 \\
$\begin{array}{l}\text { a. Predictors: (Constant), } \mathrm{x} 2 \mathrm{~m} 2, \mathrm{x} 1, \mathrm{x} 2, \mathrm{x} 1 \mathrm{~m} 2, \mathrm{x} 1 \mathrm{~m} 1, \mathrm{x} 2 \mathrm{~m} 1 \\
\text { b. Dependent Variable: } \mathrm{y}\end{array}$ & & \\
Source: Data Processed & &
\end{tabular}

Appendix 2. F-Test Results

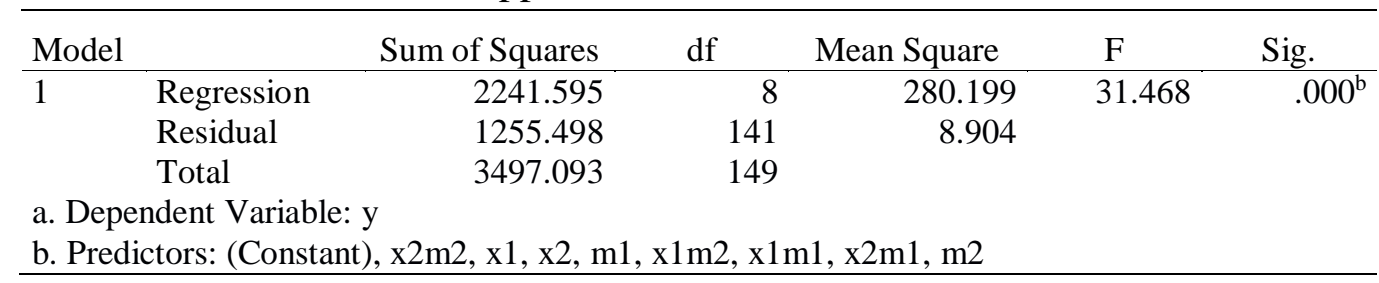

Source: Data Processed

Appendix 3. Moderated Regression Analysis (MRA)

\begin{tabular}{llccccc}
\hline & Model & \multicolumn{2}{c}{ Unstandardized Coefficients } & $\begin{array}{c}\text { Standardized } \\
\text { Coefficients } \\
\text { Beta }\end{array}$ & $\mathrm{t}$ & Sig. \\
\hline 1 & (Constant) & .317 & .620 & & .511 & .611 \\
x1 & .211 & .059 & .384 & 3.506 & .001 \\
x2 & .342 & .083 & .446 & 4.133 & .000 \\
x1m1 & .765 & .103 & 7.850 & 7.424 & .000 \\
x2m1 & .857 & .138 & 8.320 & 6.228 & .000 \\
x1m2 & .583 & .216 & 2.977 & 2.696 & .088 \\
& x2m2 & -.554 & .329 & -6.385 & -4.731 & .000 \\
\hline
\end{tabular}

Source: Data Processed 